\title{
Remote Sensing for Land Administration
}

\author{
Rohan Bennett $^{1,2, * \mathbb{D}}$, Peter van Oosterom ${ }^{3} \mathbb{D}$, Christiaan Lemmen ${ }^{2,4} \mathbb{D}^{\mathbb{D}}$ and Mila Koeva ${ }^{4}(\mathbb{D}$ \\ 1 Swinburne Business School, Swinburne University of Technology, Hawthorn 3122, Victoria, Australia \\ 2 Kadaster International, Land Registry and Mapping Agency of the Netherlands, \\ 7311 KZ Apeldoorn, The Netherlands; chrit.lemmen@kadaster.nl \\ 3 Faculty of Architecture and the Built Environment, Delft University of Technology, \\ 2600 AA Delft, The Netherlands; p.j.m.vanoosterom@tudelft.nl \\ 4 ITC Faculty, University of Twente, 7500 AE Enschede, The Netherlands; m.n.koeva@utwente.nl \\ * Correspondence: rohanbennett@swin.edu.au
}

Received: 29 July 2020; Accepted: 30 July 2020; Published: 4 August 2020

check for updates

\begin{abstract}
Land administration constitutes the socio-technical systems that govern land tenure, use, value and development within a jurisdiction. The land parcel is the fundamental unit of analysis. Each parcel has identifiable boundaries, associated rights, and linked parties. Spatial information is fundamental. It represents the boundaries between land parcels and is embedded in cadastral sketches, plans, maps and databases. The boundaries are expressed in these records using mathematical or graphical descriptions. They are also expressed physically with monuments or natural features. Ideally, the recorded and physical expressions should align, however, in practice, this may not occur. This means some boundaries may be physically invisible, lacking accurate documentation, or potentially both. Emerging remote sensing tools and techniques offers great potential. Historically, the measurements used to produce recorded boundary representations were generated from ground-based surveying techniques. The approach was, and remains, entirely appropriate in many circumstances, although it can be timely, costly, and may only capture very limited contextual boundary information. Meanwhile, advances in remote sensing and photogrammetry offer improved measurement speeds, reduced costs, higher image resolutions, and enhanced sampling granularity. Applications of unmanned aerial vehicles (UAV), laser scanning, both airborne and terrestrial (LiDAR), radar interferometry, machine learning, and artificial intelligence techniques, all provide examples. Coupled with emergent societal challenges relating to poverty reduction, rapid urbanisation, vertical development, and complex infrastructure management, the contemporary motivation to use these new techniques is high. Fundamentally, they enable more rapid, cost-effective, and tailored approaches to $2 \mathrm{D}$ and $3 \mathrm{D}$ land data creation, analysis, and maintenance. This Special Issue hosts papers focusing on this intersection of emergent remote sensing tools and techniques, applied to domain of land administration.
\end{abstract}

Keywords: UAV; LiDAR; automated feature extraction; cadaster; land registration; land use planning; SDGs

\section{Introduction}

Land administration is the process of recording, securing, and disseminating information about land tenure, value, use, and development, within a jurisdiction [1]. As a study area, soft systems methodology, socio-technical systems, and geo-information science provide contemporary theoretical foundations [2]. Conventionally, the primary unit of concern is the land parcel-a multi-dimensional spatial extent, with associated rights, and a party who is said to hold those rights [3]. In practice, land administration aggregates all the land parcel information into a system, enabled through the mandate of prescribed administrative roles, processes, and supportive technologies [4]. The functioning 
system enables land dispute resolution, transaction controls, credit access, land transfer, land valuation, land taxation, changes in land use, and development decisions [5]. Modern land administration systems utilize information technology: existing paper records are digitized, manual recording and dissemination processes digitalized, with all aspects being constituted into a publicly accessible land information system [6].

In more developed contexts, land administration systems have generally developed, over the centuries, from narrowly purposed land registries and cadastres, into whole-of-jurisdiction multi-purpose systems, to support the contemporary policy objectives of good governance and sustainable development [7,8]. In developing contexts, much effort is afforded in establishing or renewing systems. Challenges stemming from anachronous colonial-era systems; limited techniques for recording customary forms of tenure; the lack land rights records of women; the want of legal documentation for the legitmate rights of the poor and vulnerable; and scarce technical skills and capacity-all conspire to impede responsible land administration development [9-11]. Meanwhile, all systems, regardless of the country context, are challenged by the emergent demands of rapid urbanization, climate-change response, digital transformation (and e-services), gender equality, and demands for openness and transparency [12,13]. In practical terms, this results in research, development and implementations relating to 3D (and 4D) cadastres [14,15], domain standardization and interoperability [3,16,17] (e.g., ISO 19152 Land Administration Domain Model LADM and ISO TC211), land rights fractionalization and new database structures [18] (e.g., big data analytics, NoSQL, and blockchain), fit-for-purpose land administration [19], and novel land data collection approaches [20-22].

The abovementioned developments confirm spatial information is a central concern of land administration systems. Spatial information delineates the boundaries between lands parcels. These boundaries can be 'general' or 'fixed' in nature [1]. To be recognized, the boundaries require 'perception' of existence by a community; an explicitly defined 'purpose'; an actual or physical field 'presence', a defined 'period-in-time' of application, and a 'presentation' or documented representation (which may be digital) [23]. More recently, clarification of the interrelationship between the physical, documented, and digital aspects is provided [24,25].

Conventionally, ground-based survey methods, often underpinned by local or national geodetic networks, support making observations, demarcating boundaries, and surveying boundary information. This in turn enables the derivation of boundary coordinates [24]. These coordinates enable a parcel to be recorded and represented on survey sketches, cadastral plans, cadastral maps, and in the contemporary era, cadastral databases. Over time, surveying tools and techniques have improved: rudimentary rope surveys, plane table usage, theodolite application, and electronic distance measurement (EDM), have given way to total stations and high-precision global navigation satellite systems (GNSS) (Note: whilst the survey and receiver are ground-based, the space segment (i.e. GNSS satellites) are not) $[1,8]$. These approaches have been argued to deliver the prescribed coordinate accuracies, often set, it must be said, overly bluntly, at centimeter-level in surveying laws and regulations [19].

More recently, increasing attention is afforded to applying advances in photogrammetry and remote sensing to the domain land administration. In the context of land administration, these approaches are considered 'indirect' surveying techniques, in contrast to 'direct' or ground-based methods [26]. Photogrammetry is the techniques and tools for extracting multi-dimensional geospatial information from images, needed for mapping activities [27]. Remote sensing is the process of scanning or monitoring the physical characteristics of the surface of the earth, measuring the emitted radiation at a distance. For this purpose, cameras, sensors or scanners with RGB (red, green, blue), hyperspectral, LiDAR (light detection and ranging), or RADAR (radio detection and ranging) capabilities are used. These sensors can be mounted on conventional aerial vehicles (i.e., airplanes), space-borne satellites (i.e., enabling high and very-high resolution satellite imagery (HRSI and VHRSI), unmanned aerial vehicles (UAVs), amongst others [28]. It is worth noting that whilst application of photogrammetry and remote sensing to land administration has a lengthy history [29], it is the novel tools and techniques 
emerging in those fields that drive renewed and increased interest. These are specifically focused on the transfer of 'cadastral intelligence' from human actors to machines [30], and make use of enhanced image processing tools, artificial intelligence, and machine learning techniques [31].

The abovementioned developments in remote sensing and photogrammetry, applied to land administration, are the focus of this special issue. The aim is to provide a snapshot of contemporary experimentations, demonstrations, implementations, and impacts from a diverse range of case contexts. From a broad perspective, the special issue presents: (i) comparisons of alternate remote sensing techniques for $2 \mathrm{D}$ and $3 \mathrm{D}$ data capture relevant to land administration (including UAV imagery, VHRSI, RADAR, LiDAR, and multi-spectral approaches); (ii) design and testing of techniques for 2D and 3D cadastral feature extraction from remotely-sensed data sources (including machine learning, pattern recognition, neural networks, semi-automated methods, algorithm design, and object-based approaches); (iii) modelling of data production workflows for scaled 2D and 3D cadastral production (including segmentation techniques, line extraction, contour generation, and pre/post-processing requirements); and (iv) observations from illustrative cases highlighting leading practices in data integration and utilization for 2D and 3D land administration (including both city, provincial, and national level examples). More specifically, the special issue consists of nine (9) individual works; developed by multi-disciplined research and practitioner teams; across Europe, Asia, and Africa; variously using qualitative and quantitative research methods with a diversity of daya sources; all with reference back to land administration applications (Table 1). The next section outlines each work and synthesizes the overarching contribution of the special issue.

Table 1. Remote sensing applications for land administration presented in this issue.

\begin{tabular}{|c|c|c|c|c|c|}
\hline Source & Title & Country & Applications & Techniques & Data \\
\hline $\begin{array}{l}\text { Park and } \\
\text { Song }\end{array}$ & $\begin{array}{c}\text { Discrepancy Analysis for } \\
\text { Detecting Candidate Parcels } \\
\text { Requiring Update of Land } \\
\text { Category in Cadastral Map } \\
\text { Using Hyperspectral UAV } \\
\text { Images: A Case Study in Jeonju, } \\
\text { South Korea }\end{array}$ & South Korea & $\begin{array}{l}\text { Automated land } \\
\text { use classification; } \\
\text { land tenure and } \\
\text { cadastral } \\
\text { updating; land } \\
\text { value }\end{array}$ & $\begin{array}{l}\text { Convolutional neural } \\
\text { network (CNN); } \\
\text { Inconsistency } \\
\text { comparison }\end{array}$ & $\begin{array}{l}\text { UAV } \\
\text { hyperspectral; } \\
\text { cadastral map }\end{array}$ \\
\hline Koeva et al. & $\begin{array}{l}\text { Innovative Remote Sensing } \\
\text { Methodologies for Kenyan Land } \\
\text { Tenure Mapping }\end{array}$ & Kenya & $\begin{array}{l}\text { Land tenure and } \\
\text { cadastral } \\
\text { mapping }\end{array}$ & $\begin{array}{l}\text { UAV survey; Machine } \\
\text { learning; Nominal } \\
\text { Group Technique (NGT); } \\
\text { Semi-Structured } \\
\text { Interviews; } \\
\text { Questionnaires; Group } \\
\text { Discussion }\end{array}$ & $\begin{array}{l}\text { UAV RGB; sketch } \\
\text { maps; human } \\
\text { perceptions }\end{array}$ \\
\hline $\begin{array}{l}\text { Lee and De } \\
\text { Vries }\end{array}$ & $\begin{array}{l}\text { Bridging the Semantic Gap } \\
\text { between Land Tenure and EO } \\
\text { Data: Conceptual and } \\
\text { Methodological Underpinnings } \\
\text { for a Geospatially Informed } \\
\text { Analysis }\end{array}$ & North Korea & $\begin{array}{l}\text { Land tenure and } \\
\text { cadastral } \\
\text { mapping; land } \\
\text { use change }\end{array}$ & $\begin{array}{l}\text { Research synthesis; } \\
\text { Manual image } \\
\text { interpretation }\end{array}$ & $\begin{array}{l}\text { HRSI and aerial } \\
\text { RGB (Google } \\
\text { Earth); Landsat7; } \\
\text { academic } \\
\text { literature }\end{array}$ \\
\hline Koeva et al. & $\begin{array}{c}\text { Towards 3D Indoor Cadastre } \\
\text { Based on Change Detection from } \\
\text { Point Clouds }\end{array}$ & $\begin{array}{l}\text { The } \\
\text { Netherlands }\end{array}$ & $\begin{array}{l}\text { Land tenure and } \\
\text { cadastral } \\
\text { updating }\end{array}$ & $\begin{array}{l}\text { Point cloud change } \\
\text { detection techniques }\end{array}$ & $\begin{array}{l}\text { Point clouds } \\
\text { (mobile mapping } \\
\text { system, } \\
\text { Zeb-Revo); Riegl; } \\
\text { architectural } \\
\text { plans }\end{array}$ \\
\hline Yan et al. & $\begin{array}{l}\text { Towards an Underground } \\
\text { Utilities 3D Data Model for } \\
\text { Land Administration }\end{array}$ & Singapore & $\begin{array}{l}\text { Land tenure and } \\
\text { cadastral } \\
\text { mapping; land } \\
\text { use and } \\
\text { development }\end{array}$ & $\begin{array}{l}\text { 3D modelling and } \\
\text { visualisation }\end{array}$ & $\begin{array}{c}\text { Stream EM GPR } \\
\text { and Leica } \\
\text { Pegasus Two } \\
\text { photo and laser } \\
\text { scanning data; } \\
\text { cadastral data }\end{array}$ \\
\hline
\end{tabular}


Table 1. Cont

\begin{tabular}{|c|c|c|c|c|c|}
\hline Source & Title & Country & Applications & Techniques & Data \\
\hline Fetai et al. & $\begin{array}{l}\text { Extraction of Visible Boundaries } \\
\text { for Cadastral Mapping Based on } \\
\text { UAV Imagery }\end{array}$ & Slovenia & $\begin{array}{l}\text { Land tenure and } \\
\text { cadastral } \\
\text { updating and } \\
\text { mapping }\end{array}$ & $\begin{array}{c}\text { Exelis Visual } \\
\text { Information Solutions } \\
\text { (ENVI) feature } \\
\text { extraction }\end{array}$ & $\begin{array}{l}\text { UAV RGB; GNSS; } \\
\text { cadastral map }\end{array}$ \\
\hline $\begin{array}{c}\text { Claudia } \\
\text { Stöcker et al. }\end{array}$ & $\begin{array}{l}\text { Unmanned Aerial System } \\
\text { Imagery, Land Data and User } \\
\text { Needs: A Socio-Technical } \\
\text { Assessment in Rwanda }\end{array}$ & Rwanda & $\begin{array}{l}\text { Land Use; Land } \\
\text { Tenure; Land } \\
\text { Development } \\
\text { Cadastral } \\
\text { Updating }\end{array}$ & $\begin{array}{c}\text { NGT; interviews; } \\
\text { workshop; UAV survey }\end{array}$ & $\begin{array}{l}\text { UAV RGB; GNSS; } \\
\text { cadastral map }\end{array}$ \\
\hline
\end{tabular}

\section{Overview of Contributions}

The works making up this Special Issue are presented in reverse chronological order of acceptance. This was considered the most straight forward approach to administer and was also deemed to be the most unbiased. Further justification lies in the fact that whilst there are demonstratable clusters of like-contributions in terms of geographic focus, applications, techniques, and data used, the number of contributions (9) is not considered onerous to comprehend, and each individual work brings its own unique contribution.

First, inspired to deliver an alternative to ground-based surveying for the collection of non-boundary cadastral information, Park and Song [32] present a study aimed at remote identification of the discrepancy between existing cadastral maps (which include use information), and current on-ground land uses. The proposed method involves updating the existing land cover attributes of a land parcel maps using UAV hyperspectral imagery classified using CNN, and then composing a discrepancy map showing land use differences. The experimental results out of South Korea demonstrate performance relies heavily on the classification. An advantage of the approach is suggested to be its flexibility regarding modification of the matching criteria between land use categories and land coverage. The authors argue the method could be applied in other contexts and could significantly reduce the time and effort for land use monitoring and field surveying.

Second, Koeva et al. [33] introduce a suite remote sensing approaches, developed, adapted, applied, and tested for the case of land tenure recording in Kenya. These include a unique ontological analysis approach using smart sketch maps (SmartSkeMa); UAV application; and automatic boundary extraction techniques, based based on the acquired UAV images. To ensure applicability of the proposed methodologies, local community needs and the broader governance implications are examined. For the case location of Kajiado, the results show that SmartSkeMa requires little expertise for immediate use, UAVs have high potential for creating up-to-date base maps, and automatic boundary extraction appears an effective method for demarcation of visible tenure boundaries, even compared to traditional methodologies and manual delineation.

Third, Lee and de Vries [34] seek to bridge the semantic gap between land tenure concepts and remotely sensed or earth observation (EO) data. Specifically, they investigate the circumstances where it is possible to rely on EO data to inform land administration applications, such as cadastral mapping and land use change monitoring. Based on reviews of available EO data sources and techniques, they hypothesize that it is possible to both qualify and quantify specific types of land tenure. Furthermore, Lee and de Vries aim to standardize the identification and categorization of certain objects, environments, and semantics visible in EO data that can support (re-)interpretation of land tenure relations. Using North Korean as a case location, they illustrate that land tenure information, in conjunction with EO data and image interpretation, support land administration practice.

Fourth, in a continuation of earlier work, Crommelinck et al. [35] present results from a semi-automatic boundary delineation workflow, comprising image segmentation, boundary classification and an interactive delineation based on UAV data. The application of CNN for boundary line classification is shown to eliminate the previous need for Random Forest (RF) feature generation, and delivers a 71\% accuracy result. For the interactive delineation component, more intuitive delineation functionalities, covering more application cases, are presented for large data sets in Kenya, Rwanda, and Ethiopia. 
The results show that the new approach is more effective in terms of minimizing clicks and time requirements, compared to manual delineation of visible parcels boundaries. The most significant advantages are observed for rural areas, where the delineation effort per parcel requires $38 \%$ less time and $80 \%$ fewer clicks, compared to manual delineation.

Fifth, Koeva et al. [36] investigate the emerging areas of 3D cadastres and indoor boundary recording. They demonstrate that most 3D cadastre research has focused on interrelations at the level of buildings and infrastructures: analysis of interrelations in terms of indoor spaces has yet to be adequately explored. The promising research illustrates the opportunity to use 3D point clouds to establish 3D cadastral boundary data in indoor environments. The internal geometry changes of a building, temporally speaking, can be automatically detected from point clouds. The geometry changes can be linked with a data model such as LADM and included in a 3D spatial database, to support updating a 3D cadastre. The permanent changes (e.g., to walls and rooms) are automatically distinguished from dynamic changes (e.g., human, furniture) and are able to be linked to the space subdivisions.

Sixth, Yan et al. [37] head below the surface to tackle the issue of underground land tenure mapping and land use recordation. Increasing urban density and activity is resulting in public infrastructures moving underground. However, precise and detailed spatial information of underground infrastructure, the ownership of those underground objects, and knowledge on the interdependence of infrastructures below and above the ground is still often missing. The research explores how to create reliable 3D underground utility network maps for use in land administration. They investigate current issues pertaining to existing underground utility databases, using Singapore as a case study. A framework for underground utility data governance is proposed to manage the work process from data capture to data usage. An initial design of the 3D underground utility data model is introduced. It describes 3D geometric and spatial information about underground utilities data, and connects it to the cadastral parcel for land administration. Additionally, data from mobile Ground Penetrating Radar is integrated with the existing utility data in a 3D model in support of land administration of underground utilities.

Seventh, Xia et al. [38] explore the potential of deep FCNs for the novel application of cadastral boundary detection in urban and semi-urban areas, based on UAV images. They test the performance of FCNs against other state-of-the-art machine learning techniques, including MRS and gPb, in two case study sites in Rwanda. Experimental results show that FCNs outperformed MRS and gPb in both study areas and achieved an average accuracy of 0.79 in precision, 0.37 in recall and 0.50 in F-score. Therefore, they are able to effectively extract cadastral boundaries, especially when a large proportion of cadastral boundaries are visible. This automated method could minimize manual digitization and reduce fieldwork, thus facilitating the current cadastral mapping and updating practices.

Eigth, Fetai et al. [39] seek to further developments on automated boundary extraction, based on the use of high-resolution optical sensors mounted on UAV platforms. They investigate the potential of the ENVI feature extraction (FX) module for data processing using Slovenia as a case location. The results of the accuracy assessment showed that almost $80 \%$ of the extracted boundaries are correct, when compared to the reference data. Fetai et al. argue the proposed workflow has the potential to accelerate and facilitate the creation of cadastral maps, especially for developing countries. However, they caution that the boundaries must be validated by landowners and other beneficiaries after being extracted.

Finally, in a detailed socio-technical study for Rwanda, Stöcker et al. [40] determine the overarching alignment between land administration stakeholder perceptions, the characteristics of the UAV data acquisition workflows, and the final spatial data products obtainable. Additionally, three different UAVs are tested for the quality of data obtainable and the possibilities for using of the technology within the current institutional setting. A priority list of needs for cadastral and non-cadastral information, as well as insights into operational challenges, and data quality measures, of UAV-based data products is presented. It is concluded from the results that UAVs match most of the prioritized needs in Rwanda. However, it is also revealed that institutional and capacity conditions undermine the potential. 
Overall, the selected works in this Special Issue demonstrate the growing opportunities for applying innovations in remote sensing and photogrammetry (including laser scanning) to the domain of land administration. This applies to outdoor, indoor, underground, and above ground environments. The opportunities highlighted cover a wide range of land administration applications, from 2D land tenure data capture, cadastral updating, land use classification in developing contexts, through to underground utilities administration, 3D cadastral development, and indoor boundary identification in more developed contexts. The range of available and applicable remotely sensed data types and techniques is shown to be highly relevant to the land sector, and this should encourage further fusion of the disciplines into the future.

Author Contributions: Conceptualization and writing—original draft preparation, R.B.; writing—review and editing, M.K., P.v.O., C.L. All authors have read and agreed to the published version of the manuscript.

Funding: This research received no external funding.

Acknowledgments: The authors would like the acknowledge the support of colleagues at academic and governmental organisations that supported this work, in particular Kadaster Netherlands, Swinburne University of Technology, ITC Faculty University of Twente, and TU Delft.

Conflicts of Interest: The authors declare no conflict of interest.

\section{References}

1. Dale, P.; McLaughlin, J. Land Administration; Oxford University Press: Oxford, UK, 2000.

2. Çağdaş, V.; Stubkjær, E. Doctoral research on cadastral development. Land Use Policy 2009, 26, 869-889. [CrossRef]

3. Lemmen, C.; Van Oosterom, P.; Bennett, R. The land administration domain model. Land Use Policy 2015, 49, 535-545. [CrossRef]

4. Enemark, S.; Williamson, I.; Wallace, J. Building modern land administration systems in developed economies. J. Spat. Sci. 2005, 50, 51-68. [CrossRef]

5. Henssen, J. Land Registration and Cadastre Systems: Principles and Related Issues. In Lecture Notes of Technische Universität München; Technische Universität München: München, Germany, 2010.

6. Bennett, R.; Wallace, J.; Williamson, I. Organising land information for sustainable land administration. Land Use Policy 2008, 25, 126-138. [CrossRef]

7. Williamson, I.; Ting, L. Land administration and cadastral trends-A framework for re-engineering. Comput. Environ. Urban Syst. 2001, 25, 339-366. [CrossRef]

8. Williamson, I.; Enemark, S.; Wallace, J.; Rajabifard, A. Land Administration for Sustainable Development; ESRI Press Academic: Redlands, CA, USA, 2010.

9. Zevenbergen, J.; De Vries, W.; Bennett, R.M. (Eds.) Advances in Responsible Land Administration; CRC Press: Boca Raton, FL, USA, 2015.

10. Zevenbergen, J.; Augustinus, C.; Antonio, D.; Bennett, R. Pro-poor land administration: Principles for recording the land rights of the underrepresented. Land Use Policy 2013, 31, 595-604. [CrossRef]

11. Hendriks, B.; Zevenbergen, J.; Bennett, R.; Antonio, D. Pro-poor land administration: Towards practical, coordinated, and scalable recording systems for all. Land Use Policy 2019, 81, 21-38. [CrossRef]

12. Bennett, R.; Rajabifard, A.; Williamson, I.; Wallace, J. On the need for national land administration infrastructures. Land Use Policy 2012, 29, 208-219. [CrossRef]

13. Bennett, R.; Rajabifard, A.; Kalantari, M.; Wallace, J.; Williamson, I. Cadastral futures: Building a new vision for the nature and role of cadastres. In Proceedings of the FIG Congress, Sydney, Australia, 11-16 April 2010; pp. 11-16.

14. van Oosterom, P.; Bennett, R.; Koeva, M.; Lemmen, C. 3D Land Administration for 3D Land Uses. Land Use Policy 2020, 104665. [CrossRef]

15. Stoter, J.E.; van Oosterom, P. 3D Cadastre in an International Context: Legal, Organizational, and Technological Aspects; CRC Press: Boca Raton, FL, USA, 2006.

16. ISO. Geographic Information —Land Administration Domain Model (LADM); International Standard ISO 19152; ISO: Geneva, Switzerland, 2012. 
17. Shnaidman, A.; van Oosterom, P.; Lemmen, C. LADM Refined Survey Model. In Proceedings of the 8th Land Administration Domain Model Workshop, Kuala Lumpur, Malaysia, 1-3 October 2019; van Oosterom, P., Lemmen, C., Rahman, A.A., Eds.; FIG International Federation of Surveyors: Copenhagen, Denmark, 2019; pp. 73-82.

18. Bennett, R.M.; Pickering, M.; Sargent, J. Transformations, transitions, or tall tales? A global review of the uptake and impact of NoSQL, blockchain, and big data analytics on the land administration sector. Land Use Policy 2019, 83, 435-448. [CrossRef]

19. Enemark, S.; Bell, K.C.; Lemmen, C.H.; McLaren, R. Fit-for-Purpose Land Administration; International Federation of Surveyors (FIG): Copenhagen, Denmark, 2014.

20. Koeva, M.; Bennett, R.; Gerke, M.; Crommelinck, S.; Stöcker, C.; Crompvoets, J.; Ho, S.; Schwering, A.; Chipofya, M.; Schultz, C.; et al. Towards innovative geospatial tools for fit-for-purpose land rights mapping. In International Archives of the Photogrammetry, Remote Sensing and Spatial Information Sciences-ISPRS Archives, Proceedings of the ISPRS Geospatial Week 2017, Wuhan, China, 18-22 September 2017; ISPRS: Hannover, Germany, 2017; Volume 42, pp. 37-43.

21. Asiama, K.; Bennett, R.; Zevenbergen, J. Participatory land administration on customary lands: A practical VGI experiment in Nanton, Ghana. ISPRS Int. J. Geo Inf. 2017, 6, 186. [CrossRef]

22. Lengoiboni, M.; Richter, C.; Zevenbergen, J. Cross-cutting challenges to innovation in land tenure documentation. Land Use Policy 2019, 85, 21-32. [CrossRef]

23. Bennett, R.; Kitchingman, A.; Leach, J. On the nature and utility of natural boundaries for land and marine administration. Land Use Policy 2010, 27, 772-779. [CrossRef]

24. Bennett, R.M.; Molen, P.V.; Zevenbergen, J.A. Fitted, Green, and Volunteered: Legal and Survey Complexities of Future Boundary Systems. Geomatica 2012, 66, 181-193. [CrossRef]

25. Grant, D.; Enemark, S.; Zevenbergen, J.; Mitchell, D.; McCamley, G. The Cadastral triangular model. Land Use Policy 2020, 97, 104758. [CrossRef]

26. Crommelinck, S.; Bennett, R.; Gerke, M.; Nex, F.; Yang, M.Y.; Vosselman, G. Review of automatic feature extraction from high-resolution optical sensor data for UAV-based cadastral mapping. Remote Sens. 2016, 8, 689. [CrossRef]

27. Konecny, G. Geoinformation: Remote Sensing, Photogrammetry and Geographic Information Systems; CRC Press: Boca Raton, FL, USA, 2014

28. Toth, C.; Jóźków, G. Remote sensing platforms and sensors: A survey. ISPRS J. Photogramm. Remote Sens. 2016, 115, 22-36. [CrossRef]

29. Dale, P.F.; McLaughlin, J.D. Land Information Management: An Introduction with Special Reference to Cadastral Problems in Third World Countries; Oxford University Press: Oxford, UK, 1988.

30. Bennett, R.; Asiama, K.; Zevenbergen, J.; Juliens, S. The Intelligent Cadastre. In Proceedings of the FIG Commission 7 AGM, St Juliens, Malta, 16-19 November 2015.

31. Bennett, R.M.; Gerke, M.; Crompvoets, J.; Alemie, B.K.; Crommelinck, S.C.; Stöcker, E.C. Building Third Generation Land Tools: Its4land, Smart Sketchmaps, UAVs, Automatic Feature Extraction, and the GeoCloud. In Proceedings of the Annual World Bank Conference on Land and Poverty, Washington, DC, USA, 20-24 March 2017.

32. Park, S.; Song, A. Discrepancy analysis for detecting candidate parcels requiring update of land category in cadastral map using hyperspectral UAV Images: A case study in Jeonju, South Korea. Remote Sens. 2020, 12, 354. [CrossRef]

33. Koeva, M.; Stöcker, C.; Crommelinck, S.; Ho, S.; Chipofya, M.; Sahib, J.; Bennett, R.; Zevenbergen, J.; Vosselman, G.; Lemmen, C.; et al. Innovative remote sensing methodologies for Kenyan land tenure mapping. Remote Sens. 2020, 12, 273. [CrossRef]

34. Lee, C.; de Vries, W.T. Bridging the Semantic Gap between Land Tenure and EO Data: Conceptual and Methodological Underpinnings for a Geospatially Informed Analysis. Remote Sens. 2020, 12, 255. [CrossRef]

35. Crommelinck, S.; Koeva, M.; Yang, M.Y.; Vosselman, G. Application of deep learning for delineation of visible cadastral boundaries from remote sensing imagery. Remote Sens. 2019, 11, 2505. [CrossRef]

36. Koeva, M.; Nikoohemat, S.; Oude Elberink, S.; Morales, J.; Lemmen, C.; Zevenbergen, J. Towards 3D Indoor Cadastre Based on Change Detection from Point Clouds. Remote Sens. 2019, 11, 1972. [CrossRef]

37. Yan, J.; Jaw, S.W.; Soon, K.H.; Wieser, A.; Schrotter, G. Towards an underground utilities 3D data model for land administration. Remote Sens. 2019, 11, 1957. [CrossRef] 
38. Xia, X.; Persello, C.; Koeva, M. Deep fully convolutional networks for cadastral boundary detection from UAV images. Remote Sens. 2019, 11, 1725. [CrossRef]

39. Fetai, B.; Oštir, K.; Kosmatin Fras, M.; Lisec, A. Extraction of visible boundaries for cadastral mapping based on UAV imagery. Remote Sens. 2019, 11, 1510. [CrossRef]

40. Stöcker, C.; Ho, S.; Nkerabigwi, P.; Schmidt, C.; Koeva, M.; Bennett, R.; Zevenbergen, J. Unmanned Aerial System imagery, land data and user needs: A socio-technical assessment in Rwanda. Remote Sens. 2019, 11, 1035. [CrossRef]

(C) 2020 by the authors. Licensee MDPI, Basel, Switzerland. This article is an open access article distributed under the terms and conditions of the Creative Commons Attribution (CC BY) license (http://creativecommons.org/licenses/by/4.0/). 